\title{
Cellular oxidative stress stimulated by microcystin: review
}

\author{
Estresse oxidativo celular estimulado por microcistina: revisão \\ Estrés oxidativo celular estimulado por microcistina: revisión
}

Received: 08/23/2021 | Reviewed: 08/29/2021 | Accept: 09/03/2021 | Published: 09/05/2021

\author{
Iara Bezerra de Oliveira \\ ORCID: https://orcid.org/0000-0003-1382-7296 \\ Federal University of Campina Grande, Brazil \\ E-mail: iara_bio@yahoo.com.br \\ Hanndson Araújo Silva \\ ORCID: https://orcid.org/0000-0001-8914-9589 \\ Federal University of Campina Grande, Brazil \\ E-mail: hanndson@gmail.com
}

\begin{abstract}
Introduction: Cyanobacteria are organisms capable of producing a high number of bioactive molecules, known as cyanotoxins. Among the cyanotoxins, microcystins stand out, compounds with hepatotoxic potential. Studies claim that the most common and most toxic isoform among microcystins is microcystin-LR. One of the most frequently detected properties of microcystins is their ability to generate cellular oxidative stress. Thus, the present study is a bibliographic research about the biochemical mechanism of free radical generation caused by Microcystin LR. Methodology: for the preparation of this review, a survey was carried out in the national and international literature. The inclusion criteria for the construction of this work were original and review articles that addressed the ability of microcystin LR to generate oxidative damage. Results: Once they enter the body, microcystins accumulate in the liver, so that toxicity is associated with specific inhibition of protein phosphatase 1 and 2A (PP1 and PP2A), leading to disruption of cell integrity. Studies prove that MCs produce oxidative stress in vitro and in vivo and that they can act as tumor promoters. Conclusion: there is a possible relationship between cellular oxidative stress caused by microcystin. Thus, cyanobacterial blooms represent a threat to the health of several animals, including man, however, further studies on the topic addressed are needed.
\end{abstract}

Keywords: Free radicals; Cyanotoxins; Toxicity.

\section{Resumo}

Introdução: Cianobactérias são organismo capazes de produzir um alto número de moléculas bioativas, conhecidas como cianotoxinas. Dentre as cianotoxinas destaca-se as microcistinas, compostos com potencial hepatotóxico. Estudos afirmam que a isoforma mais comum e mais tóxica entre as microcistinas é a microcistina-LR. Uma das propriedades das microcistinas mais frequentemente detectadas é a sua capacidade de gerar estresse oxidativo celular. Desse modo, o presente estudo trata-se de uma pesquisa bibliográfica acerca do mecanismo bioquímico de geração de radicais livres ocasionado pela Microcistina LR. Metodologia: para a elaboração desta revisão foi realizado um levantamento na literatura nacional e internacional. Os critérios de inclusão para construção desse trabalho foram artigos originais e de revisão que abordavam a capacidade da microcistina LR gerar o dano oxidativo. Resultados: As microcistinas, uma vez que entram no organismo, se acumulam no fígado, de modo que a toxicidade está associada à inibição específica da proteína fosfatase 1 e 2A (PP1 e PP2A), levando a interrupção da integridade celular. Estudos comprovam que as MCs produzem estresse oxidativo in vitro e in vivo e que podem atuar como promotores tumorais. Conclusão: existe uma possível relação entre o estresse oxidativo celular ocasionados pela microcistina. Assim, as florações de cianobactérias representam uma ameaça à saúde de diversos animais, inclusive o homem, no entanto, se faz necessário mais estudos acerca do tema abordado.

Palavras-chave: Radicais livres; Cianotoxinas; Toxicidade.

\section{Resumen}

Introducción: Las cianobacterias son organismos capaces de producir un elevado número de moléculas bioactivas, conocidas como cianotoxinas. Entre las cianotoxinas destacan las microcistinas, compuestos con potencial hepatotóxico. Los estudios afirman que la isoforma más común y más tóxica entre las microcistinas es la microcistinaLR. Una de las propiedades de las microcistinas detectadas con mayor frecuencia es su capacidad para generar estrés oxidativo celular. Así, el presente estudio es una investigación bibliográfica sobre el mecanismo bioquímico de generación de radicales libres causado por Microcystin LR. Metodología: para la elaboración de esta revisión se realizó un relevamiento en la literatura nacional e internacional. Los criterios de inclusión para la construcción de este trabajo fueron artículos originales y de revisión que abordaron la capacidad de la microcistina LR para generar daño oxidativo. Resultados: una vez que ingresan al cuerpo, las microcistinas se acumulan en el hígado, por lo que la 
toxicidad se asocia con la inhibición específica de la proteína fosfatasa 1 y 2A (PP1 y PP2A), lo que conduce a la alteración de la integridad celular. Los estudios demuestran que los MC producen estrés oxidativo in vitro e in vivo y que pueden actuar como promotores de tumores. Conclusión: existe una posible relación entre el estrés oxidativo celular causado por microcistina. Por lo tanto, las floraciones de cianobacterias representan una amenaza para la salud de varios animales, incluido el hombre, sin embargo, se necesitan más estudios sobre el tema abordado.

Palabras clave: Radicales libres; Cianotoxinas; Toxicidad.

\section{Introduction}

Climate change is transforming ecosystems and their composition across the planet. In recent years, studies have indicated eutrophication, increased $\mathrm{CO} 2$ levels and global warming as responsible for the frequency, intensity and duration of cyanobacterial proliferation in different ecosystems worldwide (Rastogi, et al, 2014).

Eutrophication is considered one of the main events that affect water bodies and, consequently, water parameters. The eutrophication process interferes with the physical and chemical characteristics of the water and can mediate profound changes in the qualitative and quantitative conditions of aquatic communities. In this way, several problems are induced, such as the proliferation of toxic algae, known as cyanobacteria (Carpenter, 2005; Dhanam, et al, 2016).

Cyanobacteria are prokaryotic and photosynthetic microorganisms present in the most diverse terrestrial environments. Planktonic representatives are of special interest, as a result of ecological success and competitive strategies, they are among the pioneer organisms of terrestrial life and present themselves to the present day, producing a range of secondary metabolites that increasingly arouse scientific interest (Carmichael, 1994; Carmichael \& Boyer, 2016). Cyanobacteria were pioneering organisms on primitive Earth, and the oxygen produced through photosynthesis for the cyanobacteria contributed to the formation of the ozone layer. However, these microorganisms are currently known for their potentially toxic flowering, causing problems for water treatment and being of potential risk to human health (Szlag, et al, 2015).

Known as cyanotoxins, the metabolites produced by cyanobacteria in natural concentrations are toxic to plants, invertebrates and vertebrates, including humans. Those, in turn, comprise several classes, with different mechanisms of action and their own characteristics (Chorus, 2000).

The accelerated growth of cyanobacteria and the formation of blooms lead to a potential increase in the concentration of toxins in the water, which represents a serious risk to public health. Toxins, produced by cyanobacteria, can cause changes in the taste, odor of water, and cause toxicity in aquatic biota, which can lead animals to death from liver failure and the development of cancerous tumors. They can also accumulate in the tissues of fish intended for human consumption. In addition, the long-term effects of cyanotoxins in humans are still unclear (Carmichael \& Boyer, 2016; Janssen, 2019; Metcalf \& Codd, 2020).

In the case of cyanotoxins, liver toxins, such as microcystins (MCs), are the most abundant and widely studied natural toxins (Teneva, et al., 2016). More than 90 variants of CM have been detected (Pearson, et al, 2010), among which microcystin-LR (MC-LR) is the most widely distributed and toxic (Gupta, et al., 2003; Rastogi, et al., 2014). It is known that MC-LR is a hepatotoxin that acts in the intense inhibition of intracellular serine / threonine phosphatases 1 and $2 \mathrm{~A}$ (PP1 and PP2A) (MacKintosh, et., 1995). Because of this inhibition, an imbalance of cell phosphorylation occurs, culminating in a cell signaling disorder (Humpage \& Falconer, 2003; Sotton, et al., 2012). In addition, it can cause oxidative stress due to the intracellular excess of reactive oxygen species (ROS) considered, therefore, another important mechanism of hepatotoxicity MC-LR (Ma, et al., 2017). Studies reveal that apoptosis induced by MC-LR is possibly mediated by the mitochondrial pathway where ROS and transcription factor such as NF-kB and p53 may be involved (Fu, et al., 2005; Feng, et al., 2011; Ji, et., 2011).

In these terms, the present study aimed to collect and summarize detailed and available data on the occurrence of 
cyanotoxins worldwide and the human and animal intoxications associated with cyanotoxins. Seeking to provide an in-depth analysis, which this information providers of its toxic potential, as well as providing a discussion of its toxicity in the activity related to the generation of reactive oxygen species and consequently generation of cellular oxidative damage, in order to understand the risks to human health caused by MCs.results.

\section{Methodology}

This research can be considered of the conceptual-theoretical type because it focuses on conducting a systematic literature review, followed by a structured analysis of the contents published on the subject. An inductive analysis method is adopted because, based on the information collected in the publications, their analysis and classification, the logical structure on the topics that involve the theme presented follows an inference criterion. Systematic literature review is a reliable research approach due to its comprehensiveness and explicit presentation of the means and results obtained. Compared to the traditional review, it includes a clear statement of the purpose of the review, a thorough search for publications, a critical evaluation of the main publications and the possibility of replicating the research method. (Pai, et al., 2004).

In the present study, was carried out with a search for articles in the Pubmed, Science Direct, SciELO databases, between the months of April 2020 and June 2021, using the descriptors according to the theme. Thus, the research of articles was divided into 2 parts, of which the objective would be to list the information more precisely for each survey, with the keywords:1) "Oxidative Stress"; "Cyanotoxin" and "Microcystin": to conduct a literature survey that addressed the biochemical mechanisms of cellular oxidative stress and the toxicology of cyanotoxins. 2) "Cyanotoxin and Oxidative Stress" and "Microcystin and Oxidative Stress": to obtain studies that addressed the relationship of cyanotoxins with cellular oxidative stress.

The articles were selected after reading the title and abstract, and the inclusion criteria were: articles published any year dealing with cyanotoxins and oxidative stress, and from 2010 to 2021 on the relationship of oxidative stress and microcystins, available in full and that dealt with the theme.

\section{Cyanobacteria}

\section{Cyanotoxins}

Cyanotoxins are toxins produced by some species of cyanobacteria in fresh or salt water. These toxic substances can be stored in the cell's cytosol and are released if cell lysis occurs, they are classified as hepatotoxins (microcystin and nodularin), neurotoxins (anatoxin-a, homoanatoxin-a and saxitoxin), cytotoxins (cylinderspermopsin) and dermatoxins (lingbiatoxin) (Carmichael \& Boyer, 2016) (See Table 1). Some of the most important roles that cyanotoxins can play for the algae that produce them are to prevent the herbivore, as they can function as allopathic substances and even as signaling molecules between species and individuals (Carmichael, 1994; Svirčev, et al., 2017). Some of these toxins, which are characterized by their rapid action, causing death by respiratory arrest after a few minutes of exposure, have been identified as neurotoxic alkaloids or organophosphates. Others act less quickly and are identified as hepatotoxic peptides or alkaloids. These are the two main groups of cyanotoxins that can be classified as: neurotoxins and hepatotoxins (Azevedo, 1998; Andrinolo, et al., 1998). 
Table 1: Classification as to the pharmacological action and chemical structure of the main cyanotoxins.

\begin{tabular}{|c|c|c|}
\hline ACTION & STRUCTURE & TYPE \\
\hline Hepatotoxins & Cyclic Peptides & $\begin{array}{c}\text { Microcystin } \\
\text { Nodularin }\end{array}$ \\
\cline { 2 - 3 } & Alkaloid & Cylinderspermopsin \\
\hline Dermatotoxins & Lipid and Carbohydrate & Lipopolisacaride \\
\hline & & \\
\hline Neurotoxins & Alkaloid & $\begin{array}{c}\text { Saxitoxin } \\
\text { Anatoxin- } a \\
\end{array}$ \\
& & $\begin{array}{c}\text { Homoanatoxin- } a \\
\text { Anatoxin-a }(S)\end{array}$ \\
\hline
\end{tabular}

Source: Authors.

\section{Hepatoxoxins}

The main hepatotoxins characterized so far are cyclic hepatapeptides known as microcystins and pentapeptides designated as nodularins. The general structure of microcystins is D-Ala-X-D-MeAsp-Z-Adda-D-Glu-Mdha, where X and Z are the two variable L amino acids, D-MeAsp is D-erythro metilaspartic acid and Mdha is N-methyl -hydroalanine (See Figure 1 - A) (Carmichael, 1994; Meriluoto, et al., 2016; Bouaïcha, et al., 2019).

Nodularins (NODs) are cyclic pentapeptide hepatotoxins with the overall ciclo structure (-d - erythro - $\beta$ - methylAsp (iso - bond) - - - Z - Adda - d - Glu (iso - bond) -2 - (methylamino) -2 Acid (Z) - dehydrobutyric) (See Figure 1 - B) (Meriluoto, et al., 2016). NODs share many structural and functional properties with MCs, the primary without two aminoalkanoic acid residues and showing a substitution of the N-methyl-hydroalanine residue with N-methyl-hydrobutyrine. The second aminoalkanoic acid residue $(\mathrm{Z})$ is 1-Arg within the frequently occurring nodularin-R (also referred to as "nodularin" without suffix) (Meriluoto, et al., 2016).

The qualitative variations observed in the two $\mathrm{L}$ amino acids in microcystins are used to designate their different variants, for example, microcystin-LR (leucine-arginine); -RR (arginine-arginine); -YA (tyrosine-alanine). Adda, is 3-amino-9methoxy-2,6,8-trimethyl-10-phenyl-deca-4,6-dienoic acid, which is also present in nodularins and has been determined to be responsible for the biological activity of these hepatotoxins (Meriluoto, et al.,2016; Bouaïcha, et al., 2019 ).

Hepatotoxins reach hepatocytes through bile acid receptors and promote a disorganization of the intermediate filaments and actin filaments, which are polymers of proteins that are part of the cytoskeleton (Yan, et al., 2020). This disorganization leads to a retraction of the hepatocytes, causing loss of contact between them and the cells that form the sinusoidal capillaries. Consequently, the liver loses its architecture and develops serious internal injuries. The loss of contact between the cells creates internal spaces that are filled by the blood that begins to flow from capillaries to these locations (Carmichael, 1994; Yan, et al., 2020).

Through the study of the mechanisms of action of these hepatotoxins, it was demonstrated that several microcystins and nodularins are potent inhibitors of type 1 and $2 \mathrm{~A}$ eukaryotic cell protein phosphatases. These toxins are recognized as potent liver tumor promoters (Yan, et al., 2020; Takai, et al., 2018).

Nodularins have stronger tumor initiation and promotion activities compared to MCs. this will stem from its smaller ring structure, allowing easier ingestion by hepatocytes (Carmichael, et al., 1994).

Like MCs, NODs also induce the assembly of reactive intracellular oxygen species, causing peroxidation of lipids, proteins and DNA (Žegura, et al., 2011). 
Figure 1: Structural formula of hepatotoxins, A - Microcystin and B - Nodularine.

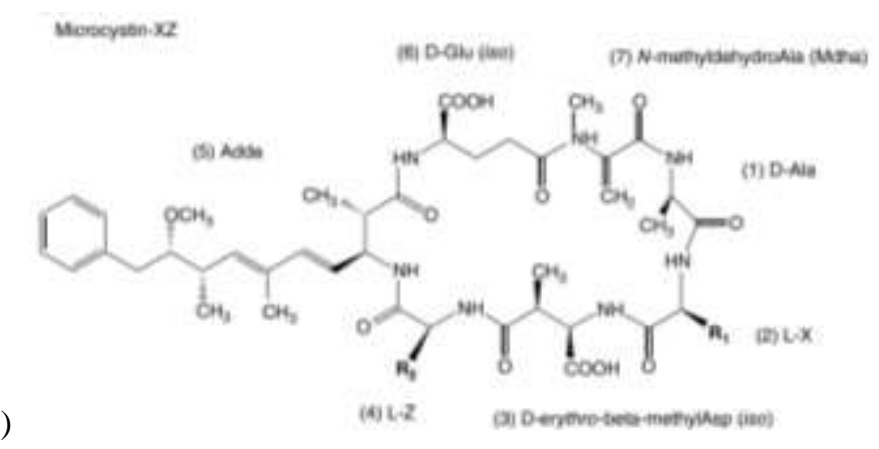

(A)

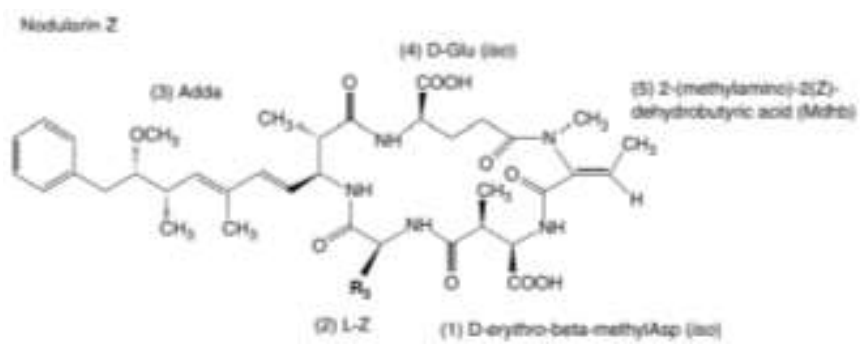

Source: Meriluoto, et al. (2017).

Cylindrospermopsins (CYNs) also are considered hepatotoxins, but they're guanidine alkaloids, produced by a series of cyanobacterial genera (Li, 2012). Currently, five CYN analogs are known, namely, CYN, 7 - epi - CYN and seven - deoxy CYN (See Figure 2) and therefore the two recently characterized congeners, 7 - deoxidesulfo - CYN and seven - deoxidesulfo 12 - acetyl - CYN (Wimmer, et al., 2014). The structures of CYN and 7-epi- CYN have repeatedly undergone name changes, with each at some point being called CYN. at the present, 7- (S) -CYN is considered the most toxin produced by Cylindrospermopsis raciborskii. supported the reassessment of absolutely the C-7 configuration of the isolated CYN, revised synthesis, and asymmetric synthesis, absolutely the configuration of all asymmetric CYN centers, 7 - epi - CYN and seven deoxy - CYN were established. it had been concluded that the names remain an equivalent as they were assigned (Meriluoto, et al., 2016).

CYN is a strong inhibitor of protein synthesis. The liver is its main target, with four successive stages of pathological alterations in: inhibition of protein synthesis, membrane proliferation, accumulation of fat droplets and cell death (Moreira, et al., 2013).

Studies show that exposure to CYN led to a decrease in the decreased glutathione (GSH) content in rat hepatocytes. This reduction has been attributed to the inhibition of GSH synthesis (Moreira, et al., 2013; Runnegar, et al. 2002).

Norris et al., 2002, suggested that the activation of CYN by cytochrome P450 is of fundamental importance in its mechanism of action. Initiation of CYN by cyt-p450 results in increased toxicity; therefore, it is regarded as a progenotoxic substance (Kinnear, 2010). In addition, oxidative stress can play a significant role in CYN toxicity in vitro (Gutiérrez-Praena, et al., 2011a), and in vivo Gutiérrez-Praena, et al., 2011b).

In general, CYN appears as a toxic molecule with wide reach. It disturbs various organs and metabolic pathways, both directly and after some metabolic alteration. The absence of a particular objective for CYN hinders further efforts to comprehend its potent toxicity and classify appropriate exposure limits (Meriluoto, et al., 2016). 
Figure 2: Structural formula of cylindropemopsin.

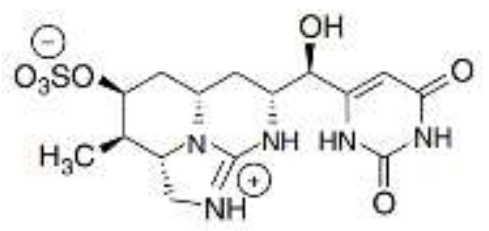

Source: Meriluoto (2007).

Among all cyanotoxins, the most common type of poisoning involving cyanobacteria is related to the presence of hepatotoxins in water bodies. Hepatotoxins act mainly on liver cells, where, by different mechanisms, they mediate the destruction of liver cells, leading all tissues to necrosis and intrahepatic hemorrhage, which results in the animal's death in a few hours in acute doses. In addition to acting on the liver, hepatotoxins can accumulate in other organs, such as kidneys, stomach, lung, brain, gonads and heart (Mohamed, et al., 2020).

\section{Neurotoxins}

Neurotoxins belong to three chemically distinct families, anatoxin-a and homoanatoxin-a, which mimics the effect of acetylcholine; anatoxin-a (s), which is an anticholinesterase, and saxitoxins, which block the sodium channels of nerve cells (Andrinolo, et al., 2008). Neurotoxins are produced by species and lineages included in the genera: Anabaena, Aphanizomenon, Oscillatoria, Trichodesmium and Cylindrospermopsis (Buratti, et al., 2017; Svirčev, et al., 2017).

Anatoxin-a (ANTX) and homoanatoxin-a (HANTX) are effective neurotoxins, created by several of cyanobacterial species. ANTXs contaminate the lakes and rivers and have been linked to several animal deaths. ANTX is characterized by a very fast death factor for animals that have consumed toxic cyanobacteria.

More ANTX derivatives have additionally been identified in samples at different concentrations. ANTX and HANTX undergo quick chemical decay in nature; the main degradation products constitute dihydro and epoxy analogs (Stevens \& Krieger, 1991).

Anatoxin-a was the first cyanobacterial toxin to be chemically and functionally defined, it is a low molecular weight secondary amine, (1 - [(1R, 6R) -9-azabicyclo [4.2.1] non-4- en-5-yl] ethanone) (See Figure 3 - A). This neurotoxic alkaloid is a potent postsynaptic neuromuscular blocker and cholinergic receptors. This action occurs because anatoxin-a binds irreversibly to acetylcholine receptors, as it is not degraded by acetylcholinesterase (Devlin, et al., 1997; Andrinolo \& Sedan, 2015; Chen \& Blatchley, 2020).

In this way, it acts on cholinergic synapses, activating the nicotinic receptors of the postsynaptic cell. The postsynaptic cell may be another neuron that will respond with the start of a nerve impulse or a muscle or effective glandular cell that will respond to the presence of contraction or anatoxin-inducing discharge, depending on the case. Unlike acetylcholine, anatoxins-a will not be deactivated by acetylcholinesterase, so that the activation signal remains "on". According to their action at the synaptic level, mammalian poisonings are characterized by intense muscle contractions and abundant salivation. Muscle cells continue to be stimulated, causing muscle contractions, fatigue and paralysis (Devlin, et al., 1977; Andrinolo \& Sedan). Signs of poisoning by this toxin in wild and domestic animals include imbalance, muscle fasciculation, wheezing and seizures. Death occurs due to respiratory arrest and occurs from a few minutes to a few hours, depending on the dosage and previous food consumption. Clinical signs of intoxication show progression of muscle fasciculation, decreased movement, exaggerated abdominal breathing, cyanosis, convulsion and culmination with death (Azevedo, 1998; Kubickova, et al., 2019). 
Another neurotoxin, later characterized, which shows the same signs of anatoxin-a poisoning, plus intense salivation, was designated as anatoxin-a (s). This neurotoxin has an action mechanism similar to anatoxin-a, as it inhibits the action of acetylcholinesterase, preventing the degradation of acetylcholine bound to receptors. Anatoxin-a (s) (See Figure 3 - B) binds to the enzyme and does not allow its interaction with acetylcholine. As acetylcholine is not deactivated, it remains in the synaptic space for a longer time, acting on nicotinic receptors. Thus, the result is similar to that described for anatoxin-a (Andrinolo \& Sedan, 2015). Another main group of toxins, the most common intoxications involving cyanobacteria are hepatotoxins, which are slower in action, causing death between a few hours and a few days, due to intrahepatic hemorrhage and hypovolemic shock. The signs observed after ingesting these hepatotoxins are prostration, anorexia, vomiting, abdominal pain and diarrhea (Azevedo, 1998; Andrinolo \& Sedan, 2015; Svirčev, et al., 2017). The species already identified as producing these hepatotoxins are included in the genera Microcystis, Anabaena, Nodularia, Oscillatoria, Nostoc and Cylindrospermopsis (Carmichael, 1994; Köker, et al., 2017; Kubickova, et al., 2019).

Another type is the saxitoxins (STXs), which are powerful neurotoxic alkaloids, manufactured by marine eukaryotic dinoflagellates and prokaryotic freshwater cyanobacteria. They constitute a notable example of toxins that are manufactured by organisms belonging to various kingdoms of life (Dittmann, et al., 2012). In freshwater conditions, STXs are mostly linked to the filamentous cyanobacteria of several genera, including Aphanizomenon, Dolichospermum (Anabaena), Lyngbya, Cylindrospermopsis, Raphidiopsis, Scytonema, Geitlerinema, Cylindrospermum and Phormidium (Borges, et al., 2015).

Saxitoxin (STX) was the first analog to be identified (Schantz, 1975). Saxitoxin and its analogs (STXs) are composed of a 3,4-peridropurine tricyclic system and have two guanidinium groups. The STX molecule can be replaced in multiple positions (See Figure 3 - C).

Currently, 57 STXs are described. Dependent about their chemical forms, STXs can be categorized into several groups, including carbamoyl toxins (C), descarbamoyl toxins (dc), N-sulfocarbamoyl toxins (G), gonyautoxins (GTX) and deoxidecarbamoyl toxins (LW) (Wiese, et al., 2010; Meriluoto, et al., 2016).

STXs are powerful neurotoxins. They are blocking voltage-gated sodium ion channels in neuronal cells, working on the extracellular sides by interacting with a neurotoxin receptor referred to as site 1 (Nakagawa, et al., 2019). Recently, it was discovered that STX also binds to the potassium and calcium channels (Llewellyn, 2006; Catterall, 2015).

Consumption of STXs by humans is leading to the syndromes known as paralytic mollusk poisoning (PMP). In serious cases, PMP causes death from lung failure. From the marine environment, about 2,000 cases of human poisoning from shellfish and fish use are reported annually with a mortality rate of roughly $15 \%$. An antidote or detox route is still not clear (Meriluoto, et al., 2016).

STXs accumulate in all aquatic food webs in marine environments. Usual vectors for STXs are filter mollusks like mussels and oysters, but are also transported by non-traditional vectors such as fish, crabs or snails to the terrestrial biota, including human beings, is caused by case PMP (Deeds, 2008). 
Figure 3: Structural formula of Neurotoxins: A - Anatoxin-a; B- Anatoxin-a (S) and C- Saxitoxin.

(A)

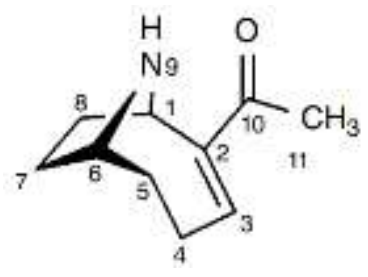

(B)

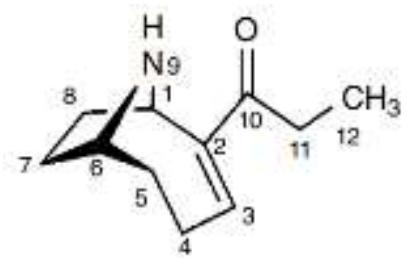

(C)

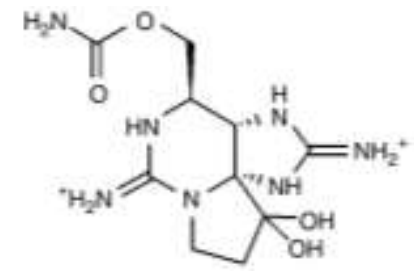

Source: Meriluoto (2007).

\section{Cyanotoxins And Health}

The increase in the population of cyanobacteria when it occurs in aquatic communities, is called flowering. The consequence is that higher concentrations of toxic cyanobacteria are responsible for producing high concentrations of cyanotoxins that can induce and mediate the death of fish and other animals, including man, through the consumption of contaminated water or organisms. Therefore, the study of cyanotoxins is important for public health (Carmichael, 1994; Melaram, 2020).

These toxins, when present in water used for domestic supply, fishing or leisure, can reach human populations and cause adverse effects such as gastroenteritis, hepato-enteritis and other diseases of the liver and kidney, cancer, skin irritations, allergies, conjunctivitis, problems with vision, muscle weakness, breathing problems, choking, convulsions and death, depending on the type of toxin, concentration and contact route. (Carmichael, 1994; Huisman, et al., 2018; Melaram, 2020) (See Table 2).

In recent years, cyanotoxins have been the subject of many studies, because they are soluble in water and pass through the conventional system that use common treatment adsorbents and, therefore, this type of treatment is unlikely to provide an efficient elimination of cyanotoxins. It is commonly understood that in most species, most toxins remain within healthy cells and are only released in lysis, which can be a consequence of natural senescence, changes in environmental conditions or during corrective practices, such as the use of algaecide in the process treatment (Teixeira, et al., 2020).

Many countries have defined their health recommendations according to the provisional guidance of the World Health Organization, which was set at $1.0 \mu \mathrm{g} / \mathrm{L}$ for microcystin-LR (Jang, et al., 2003). Therefore, the main concern with cyanotoxins is related to the presence of these toxins in reservoirs destined for public supply (Wood, 2016; Abbas, et al., 2020).

Human exposure and possible cyanotoxin poisoning are causally related to cyanobacterial cell proliferation and lysis. So, intoxication can occur in different ways: when drinking contaminated water, during the recreational use of water, especially in the presence of blooms, through contact with the skin and also when drinking water unintentionally; inhaling aerosol particles, potentially possible during showers, when playing water sports; consumption of exposed food and by hemodialysis, if the water is not treated properly (Carmichael \& Boyer, 2016; Huisman, et al., 2018).

Thus, cyanotoxins can have a toxic effect on humans and other animals, even in small concentrations. Among the most known types of toxins, they can be classified according to their mechanism of action into hepatotoxic, which are microcystins and nodularins; neurotoxic, represented by anatoxin-a, homoanatoxin-a, anatoxin-a (s) and a large group called saxitoxins; cytotoxic, cylinderspermopsin; and dermatotoxins, which are lipopolysaccharide toxins, common to several species of cyanobacteria. There are still other toxins not common: aplysiatoxin, debromoaplysiatoxin and lyngbiatoxin-a, with distinct actions, such as dermatotoxic, tumor-promoting and gastric irritants, but not yet fully elucidated (Malik, et al., 2020). 
Table 2: Cyanotoxins, genera and symptoms after exposure.

\begin{tabular}{|c|c|c|c|}
\hline Toxin & Producing Bodies & Symptoms of acute exposure & Referências \\
\hline Microcystins & $\begin{array}{c}\text { Anabaenopsis, Anabaena, } \\
\text { Aphanizomenon, } \\
\text { Aphanocapsa, } \\
\text { Arthrospira, } \\
\text { Fischerella, } \\
\text { Gloeotrichia, } \\
\text { Hapalosiphon, } \\
\text { Merismopedia, } \\
\text { Microcystis, } \\
\text { Oscillatoria, } \\
\text { Pleurocapsalean, } \\
\text { Phormidium, } \\
\text { Planktothrix, } \\
\text { Radiocystis, } \\
\text { Synechococcus, } \\
\text { Snowella, } \\
\text { Synechocystis, } \\
\text { Woronichinia } \\
\end{array}$ & $\begin{array}{c}\text { Prostration, pilo erection, } \\
\text { anorexia, nausea, vomiting, } \\
\text { abdominal pain, diarrhea, renal } \\
\text { damage; hepatotoxic, tumour } \\
\text { promoters, hypovolemic shock } \\
\text { and intrahepatic hemorrhage. } \\
\text { Death (in } \\
\text { some cases)/immediate } \\
\text { up to } 24 \mathrm{~h} .\end{array}$ & $\begin{array}{c}\text { (Falconer et al., 1983; Rinehart } \\
\text { et al., 1988; } \\
\text { Turner et al. 1990; } \\
\text { Lawton and Codd, 1991; } \\
\text { Sivonen et al., 1991; } \\
\text { Fawell et al., 1993; } \\
\text { Yu, 1994; } \\
\text { Yoshida et al., 1997; } \\
\text { Jochimsen et al., 1998; } \\
\text { Mahakhant et al., 1998; } \\
\text { dos Vieira et al., 2003; Ballot, } \\
\text { 2004; } \\
\text { Botha et al., 2004; } \\
\text { Ballot et al., 2005; } \\
\text { Carey et al., 2007; } \\
\text { Fiore et al., 2009; } \\
\text { Chen et al., 2015; } \\
\text { Spoof and Catherine, 2017). }\end{array}$ \\
\hline Nodularins & $\begin{array}{c}\text { Nodularia } \\
\text { Nostoc }\end{array}$ & $\begin{array}{c}\text { Prostration, pilo erection, } \\
\text { anorexia, vomiting, abdominal } \\
\text { pain, diarrhea, hypovolemic } \\
\text { shock and intrahepatic } \\
\text { hemorrhage. } \\
\text { Hepatotoxic, } \\
\text { tumour promoters; } \\
\text { carcinogenic.. } \\
\end{array}$ & $\begin{array}{c}\text { (Sivonen et al., 1989; } \\
\text { Soong et al., 1992; } \\
\text { Ressom et al., 1994; } \\
\text { Carmichael and Boyer, 2016; } \\
\text { Spoof and Catherine, 2017). }\end{array}$ \\
\hline Anatoxin - a & $\begin{array}{c}\text { Anabaena, } \\
\text { Aphanizomenon, } \\
\text { Arthrospira, } \\
\text { Cylindrospermum, } \\
\text { Microcystis, } \\
\text { Oscillatoria, } \\
\text { Planktothrix, } \\
\text { Raphidiopsis, } \\
\text { Tychonema(bourrellyi). }\end{array}$ & $\begin{array}{c}\text { Progressive paralysis, strong } \\
\text { abdominal breathing, cyanosis, } \\
\text { convulsion, Tingling in fingers } \\
\text { and } \\
\text { toes; dizziness, convulsions; } \\
\text { paralysis, muscle } \\
\text { fasciculation, gasping death } \\
\text { from asphyxiation. Death (in } \\
\text { some cases)/ } \\
\text { immediate up to } 1-2 \mathrm{~h} \text {. }\end{array}$ & $\begin{array}{c}\text { (Lippy and Erb, 1976; } \\
\text { Devlin et al., 1977; } \\
\text { Carmichael and Gorham, 1981; } \\
\text { Sykora and Keleti, 1981; } \\
\text { Carmichael et al.,1985; } \\
\text { Fawell and James, 1994; } \\
\text { Fitzgeorge et al., 1994; Ressom } \\
\text { et al., 1994; } \\
\text { Sivonen and Jones, 1999; } \\
\text { Ballot, 2004; } \\
\text { Ballot et al., 2005; } \\
\text { Van Apeldoorn et al., 2007; } \\
\text { Shams et al., 2015; Carmichael } \\
\text { and Boyer, 2016). }\end{array}$ \\
\hline Anatoxin-a (S) & $\begin{array}{c}\text { Anabaena lemmermannii, } \\
\text { A. flos-aquae, } \\
\text { A. spiroides. }\end{array}$ & $\begin{array}{l}\text { Progressive paralysis, muscle } \\
\text { weakness, decreased respiratory } \\
\text { rate, Hyper salivation, diarrhea, } \\
\text { exaggerated } \\
\text { abdominal breathing, } \\
\text { cyanosis, convulsions. Death } \\
\text { and survival time of } 10-30 \text { min. }\end{array}$ & $\begin{array}{c}\text { (Dillenberg and Dehnel 1960; } \\
\text { Mahmood and Carmichael, } \\
\text { 1987; } \\
\text { Matsunaga et al., 1989; } \\
\text { Carmichael et al., 1990; } \\
\text { El Saadi and Cameron 1993; } \\
\text { Stewart, 2004; } \\
\text { Van Apeldoorn et al., 2007; } \\
\text { Aráoz et al., 2010). } \\
\end{array}$ \\
\hline Cylinderspermopsin & $\begin{array}{c}\text { Anabaena } \\
\text { Aphanizomenon, } \\
\text { Chrysosporum, } \\
\text { Cylindrospermopsis } \\
\text { raciborskii, } \\
\text { Lyngbya, } \\
\text { Oscillatoria, Raphidiopsis, } \\
\text { Sphaerospermopsis, } \\
\text { Umezakia. } \\
\end{array}$ & $\begin{array}{c}\text { Nausea, vomiting, bloody } \\
\text { diarrhoea, kidney } \\
\text { damage, headache, } \\
\text { dehydration, convulsions, } \\
\text { intense salivation. Death occurs } \\
\text { from respiratory failure. }\end{array}$ & $\begin{array}{c}\text { (Byth, 1980; } \\
\text { Bourke et al., 1983; Hawkins et } \\
\text { al., 1985; } \\
\text { Ohtani et al., 1992; } \\
\text { Li et al., 2001; } \\
\text { Schembri et al., 2001; } \\
\text { Svrcek and Smith, 2004; Spoof } \\
\text { et al., 2006; } \\
\text { Seifert et al., 2007). }\end{array}$ \\
\hline
\end{tabular}




\section{Microcystin And Oxidative Stress}

Microcystins are hepatotoxins composed of a cyclic heptapeptide with more than 100 isoforms with different toxicities (Puddick, et al., 2014). Being produced by several genera of cyanobacteria, including Microcystis and Anabaena (Schreidah, et al., 2020). These toxins are considered to be very potent and widely distributed cyanotoxins, occurring worldwide. Microcystins have a strong affinity with serine / threonine protein phosphatases due to their cyclic heptapeptide structure, thus acting as potent inhibitors of the eukaryotic protein phosphatase families PP1 and PP2A, leading to cell apoptosis. Through this mechanism, microcystins induce oxidative stress in the cell. (Carmichael, 1994; Campos \& Vasconcelos, 2010; Greer, et al., 2017).

Since microcystins are recognized for their ability to cause acute poisoning, which can lead vertebrate animals, including humans, to severe liver changes, causing damage and culminating in tissue failure (Carmichael, 1994; Svirčev, et al., 2017).

Microcystin-LR (MC-LR) is the most common and most toxic isoform (See Figure 4) among microcystins, with leucine and arginine in positions 2 and 4, respectively (Ding \& Nam Ong., 2003). The lethal dose for 50\% of the exposed individuals (LD50) for mice is quite low, approximately $60 \mu \mathrm{g} \mathrm{L}^{-1}$, therefore considered highly toxic (Jang, et al., 2003).

Figure 4: General structure of microcystins (MCs) and an overview of their structure, observing diversity. $\mathrm{R} 1=\mathrm{H}$ or $\mathrm{CH} 3$; R2 $=\mathrm{H}$ or $\mathrm{CH} 3$; $\mathrm{R} 3=\mathrm{H}, \mathrm{CH} 3$ or $\mathrm{C} 3 \mathrm{H} 6 \mathrm{OH} ; \mathrm{R} 4=\mathrm{H}, \mathrm{CH} 3$ or $\mathrm{COCH} 3 ; \mathrm{X}$ and $\mathrm{Z}=$ variable L-amino acids.

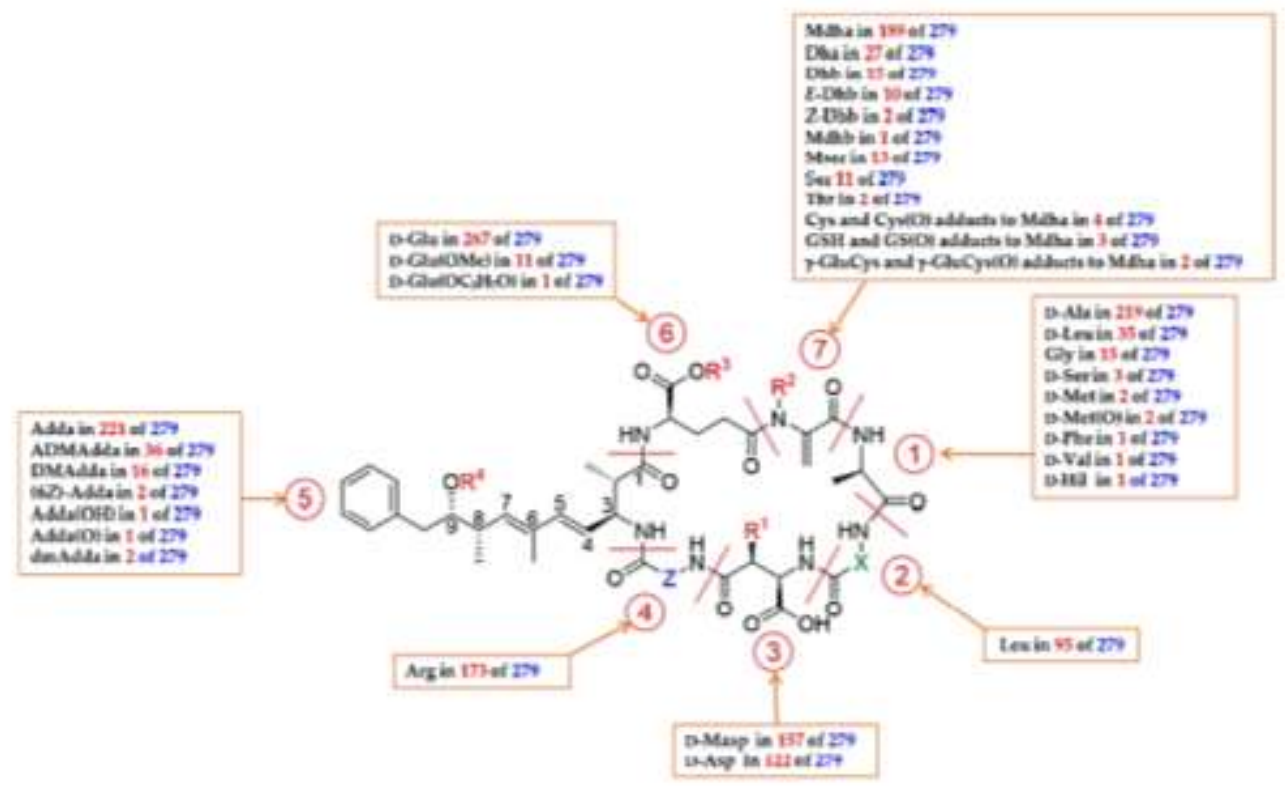

Source: Bouaicha (2019).

One of the characteristics of microcystins is the presence of the $\beta$-amino acid Adda. This amino acid has the ability to increase the overall hydrophobicity of the microcystin molecule and another unsaturated amino acid, Mdha, acts as an additional receptor (Bouaïcha, et al., 2019). Adda plays an important role in hepatotoxicity, since the removal or saturation of Adda dramatically reduces the toxicity of microcystin-LR. Adda C-7 geometric isomers in microcystins -LR and RR proved to be essentially non-toxic, but the substitution of the Adda C-9 methoxy group with acetoxy or hydroxy groups has been studied and is not able to reduce toxicity (Harada, et al., 2004).

A biochemical characteristic of MC toxicity is the production of ROS. The generation of ROS has been reported in in vitro systems, in human liver cells (Nong, et al., 2007), in fish cells (Pichardo, et al., 2007), lymphocytes (Zhang, et al., 2008) 
and human erythrocytes (Sicińska, 2006), as well as in several in vivo studies in mice and rat liver, heart and reproductive system (Ding, et al., 2001; Weng, et al., 2007; Wei, et al., 2008; Li, et al., 2008; Qiu, et al., 2009).

The generation of ROS is intrinsically related to mitochondrial metabolism and can lead to cell death due to necrosis or apoptosis. Likewise, it is believed to be involved in a number of pathologies, such as impaired heart blood pumping function and diseases in the liver and kidneys. (Weng, et al., 2007; Wei, et al., 2008; Qiu, et al., 2009).

The mechanisms of ROS production mediated by MC and cell injury are poorly understood (Wei, et al., 2008). Studies have reported for the first time the increase in $\mathrm{Ca} 2+$ in the mitochondria of rat hepatocytes in culture, as the first event that precedes apoptosis induced by MC-LR (Ding \& Ong, 2001).

After the beginning of the permeability of the carrier membrane, three important cellular events may occur (i) elevation of the ROS formation, (ii) loss of the mitochondrial membrane (MMP) potential and (iii) release of mitochondrial apoptotic factors, such as cytochrome c, triggering the execution of apoptosis (Lemasters, et al., 1998).

Another plausible mechanism for the generation of ROS is the increase in the activity of NADPH oxidase. Thus, positive regulation of CYP2E1 mRNA, an isoform of cytochrome P450 that exhibits NADPH oxidase activity, concomitant with oxidative stress in HepG2 cells induced by MC-LR, was verified. In addition, other molecules have been reported to be related to MC-LR-mediated mitochondrial dysfunction and oxidative stress (Nong, et al 2007).

The pro-apoptotic proteins of the BCL-2 family, including Bax and Bak, normally act on the mitochondrial membrane to promote the permeabilization and release of cytochrome C and ROS, important signals in the cascade of the apoptosis mechanism. Thus studies indicate that the pro-apoptotic proteins Bax and Bid were positively regulated in hepatocytes in vivo of mouse liver after oxidative stress induced by MC-LR. This positive regulation of proteins was concomitant with the loss of mitochondrial membrane potential and cell apoptosis. Pro-apoptotic proteins are known to associate to create pores in the mitochondrial membrane, therefore, capable of inducing permeabilization of the outer membrane. In addition to Ca $2+$ and CYP2E1 (membrane protein expressed at high levels in the liver), these proteins are important in oxidative stress induced by MC-LR and cellular apoptosis (Campos \& Vasconcelos, 2010). (See Figure 5).

Figure 5: Suggested pathways for MC absorption, toxicity, biotransformation and excretion in animal cells.

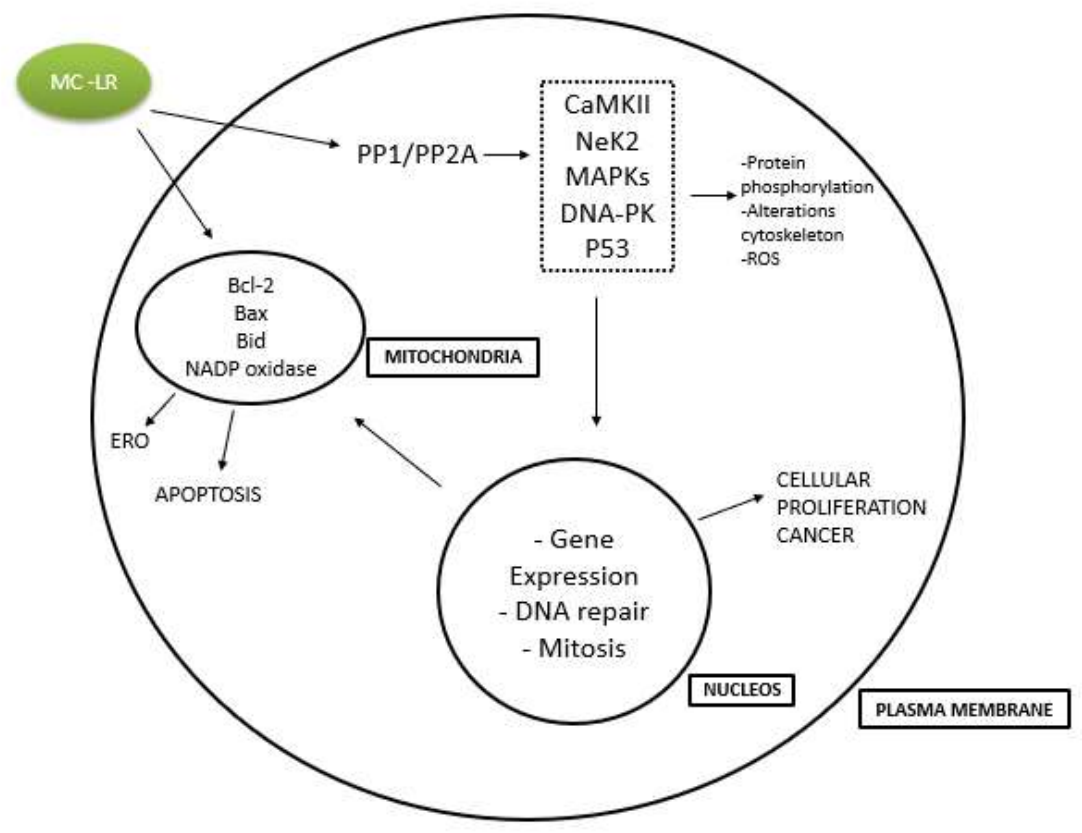

Source: Campos and Vasconcelos (2010 - Adapted). 
Likewise, Wei et al., 2008 found that the activation of the JNK protein affects some crucial enzymes of energy metabolism and leads to MC-LR-induced mitochondrial dysfunction. MC-LR has also been shown to interact directly with isolated rat kidney mitochondria. The toxin led to a strong decrease in the transmembrane potential as a result of the inhibition of redox complexes (Zareba, et al., 2007).

Microcystins can also increase oxidative stress by changing the antioxidant concentrations. It is known that reduced glutathione (GSH) is the main intracellular antioxidant with various biological purposes. GSH can participate as an indirect antioxidant or directly. In the first instance, GSH serves as a substrate for GSH peroxidase to minimize hydrogen peroxide. Additionally, GSH acts directly as a free radical hunter to react with $\mathrm{OH}, \mathrm{HOCl}$, peroxinitrito, ER and carbon-centered radicals. Therefore, the depletion of GSH often accompanies the generation of ROSs (Halliwell \& Gutteridge, 1989).

In the second situation, GSH can be combined with xenobiotics and plays a significant role in the metabolic pathway that leads to detoxification. Cellular GSH are also known to be important for the regulation of the cytoskeleton organization. Disturbance of cellular redox status by depletion of intracellular GSH has been shown to interrupt microfilament structures in human fibroblasts (Kletsas, et al., 1998). Cellular GSH was also found to be rapidly depleted within 30 minutes of exposure to microcystin (Runnegar, et al., 1987). Preprocessing of mice with GSH shielded from the lethality of microcystin (Hermansky, et al., 1991).

It was later shown that microcystin can conjugate solution with GSH and cysteine in cell-systems that and below in vivo circumstances through the Mdha portion of the microcystins (Kondo, et al., 1992). This conjugation reaction can occur under enzymatic activity by glutathione S-transferase (GST) (Pflugmacher, et al, 1998). In line with the observation above, it is also possible to verify that there has been an early reduction in intracellular GSH amounts following exposure to microcystin in cultured rat hepatocytes. Astoundingly, the GSH level increased significantly later, possibly due to the cell's identity-protection mechanisms. A precursor of GSH, significantly increased intracellular levels of GSH and decreased cytotoxicity induced by microcystin, and changes in the cytoskeleton. In contrast, butionin-sulfoximine (BSO), a specific inhibitor of GSH synthesis, improved cellular susceptibility to microcystin-induced cytotoxicity and cytoskeletal changes (Ding, et al., 2000). Consequently, all the evidence above suggests that GSH plays a crucial role in detoxifying cyanobacterial toxins.

Thus, the proliferation of cyanobacteria poses a serious threat to the aquatic environment. Because microcystin may be causing cell death for at least three routes. First, microcystin can change the antioxidant balance through early depletion of GSH, subsequently intracellular oxidative stress and oxidative injury and cell death. Second, microcystin can disrupt mitochondrial ETC, followed by ROS production and membrane permeabilization. After membrane permeabilization, mitochondrial cytochrome $\mathrm{c}$ and $\mathrm{Ca} 2+$ are released. Then, calpain and $\mathrm{Ca} 2$-dependent protein kinase II + calmodulin are activated, which ultimately leads to cell death. Third, microcystin causes cell protein phosphorylation and leads to cell death in a less explicit mechanism. (See Figure 6). 
Figure 6: A proposed model of cell events induced by microcystin.

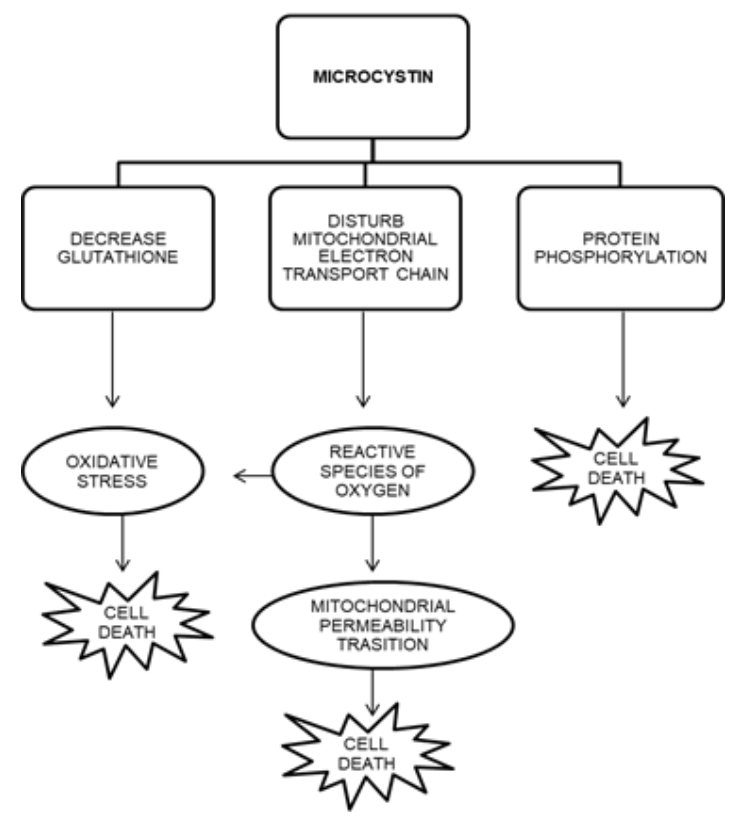

Source: Ding and Ond (2003-Adaptad).

As shown in the image above, it is possible to understand that when the production of free radicals exceeds the antioxidant defense capacity of organisms, there is an imbalance between the production of reactive species and the biological system in its ability to immediately detoxify reactive oxygen intermediates or repair the resulting damage, which can cause toxic effects through the production of peroxides and free radicals that damage all components of the cell, including proteins, lipids and DNA.

Due to the relevance of oxidative stress in the toxicity of $\mathrm{MC}$, antioxidant compounds can be considered in the prevention of animals exposed to the toxin. The compounds have been shown to extinguish free radicals, decrease oxidative stress and reduce histological damage to organisms exposed to MC (Prieto, et al., 2008).

\section{Conclusion}

MC are potent hepatotoxins with genotoxic properties. They are strong inhibitors of the serine / threonine phosphatases PP1 and PP2A. This is probably the main mechanism of action of these toxins through which it alters cellular metabolism and triggers a cascade of events that lead to necrosis or apoptosis of animal cells. MC regulates the activity of protein kinases by directly inhibiting PP1 and PP2A. This can have a strong impact on the activity of phosphoproteins, DNA repair systems and gene expression. On the other hand, the cyclic peptide appears to interact with the mitochondria of animal cells, triggering oxidative stress and apoptosis. In addition, the molecule can be inactivated in cells in a process that involves conjugation with glutathione. MC toxicity is a multi-path process and, regardless of recent achievements, the molecular mechanisms underlying MC toxicity remain elusive and a lack of knowledge persists regarding specific interaction proteins and the target of MC with the signaling pathways that trigger the cell response and the toxicity pathways of the cell injury.

Therefore, it is necessary to further study able to bring more information related to the capacity of microcystin generate cellular oxidative damage. 


\section{References}

Abbas, T., Kajjumba, G. W., Ejjada, M., Masrura, S. U., Marti, E. J., Khan, E., \& Jones-lepp, T. L. (2020). Recent advancements in the removal of cyanotoxins from water using conventional and modified adsorbents-a contemporary review. Water (Switzerland), 12(10). https://doi.org/10.3390/w12102756

Andrinolo, D., \& Sedan, D. (2015). Cianotoxinas. Farmacología y efectos de las principales toxinas Cylindrospermopsinas , Lipopolisacáridos. Cianobacterias Como Determinates Ambientales de La Salud, 49-66.

Andrinolo, D., Sedan, D., Telese, L., Aura, C., Masera, S., Giannuzzi, L., Marra, C. A., \& de Alaniz, M. J. T. (2008). Hepatic recovery after damage produced by sub-chronic intoxication with the cyanotoxin microcystin LR. Toxicon, 51(3), 457-467. https://doi.org/10.1016/j.toxicon.2007.11.012

Aráoz R, Molgó J, \& Tandeau de Marsac N (2010) Neurotoxic cyanobacterial toxins. Toxicon 56:813-828

Azevedo, S. M. F. O. (1998). Toxinas de cianobactérias : causas e conseqüências para a saúde pública. Med On Line, 1, 1-16.

Ballot, A. (2004) Cyanobacteria and cyanobacterial toxins in three alkaline Rift Valley lakes of Kenya-Lakes Bogoria, Nakuru and Elmenteita. J Plankton Res 26:925-935. https ://doi.org/10.1093/ plank t/fbh08 4

Ballot, A, Krienitz, L, Kotut, K, Wiegand, C, \& Pflugmacher, S (2005) Cyanobacteria and cyanobacterial toxins in the alkaline crater lakes Sonachi and Simbi, Kenya. Harmful Algae 4:139-150. https ://doi.org/10.1016/j.hal.2004.01.001

Borges, H. L. F., Branco, L. H. Z., Martins, M. D., Lima, C. S., Barbosa, P. T., Lira, G. A. S. T., Bittencourt-Oliveira, M. C., \& Molica, R. J. R. (2015). Cyanotoxin production and phylogeny of benthic cyanobacterial strains isolated from the northeast of Brazil. Harmful Algae, 43, 46-57. https://doi.org/10.1016/j.hal.2015.01.003

Botha, N., Gehringer, M. M., Downing, T. G., van de Venter, M., \& Shephard, E G. (2004) The role of microcystin-LR in the induction of apoptosis and oxidative stress in $\mathrm{CaCO} 2$ cells. Toxicon 43:85-92

Bouaïcha, N., Miles, C. O., Beach, D. G., Labidi, Z., Djabri, A., Benayache, N. Y., \& Nguyen-Quang, T. (2019). Structural diversity, characterization and toxicology of microcystins. Toxins, 11(12), 1-40. https://doi.org/10.3390/toxins 11120714

Bourke, A. T. C., Hawes, R. B., Neilson, A., \& Stallman, N D. (1983) An outbreak ofhepato-enteritis (the Palm Island mysterious disease) possibly caused by algal intoxication. Toxicon Suppl3:45-48.

Buratti, F. M., Manganelli, M., Vichi, S., Stefanelli, M., Scardala, S., Testai, E., \& Funari, E. (2017). Cyanotoxins: producing organisms, occurrence, toxicity, mechanism of action and human health toxicological risk evaluation. Archives of Toxicology, 91(3), 1049-1130. https://doi.org/10.1007/s00204-016-1913-6 Byth S (1980) Palm Island mystery disease. Med J Aust 2:40-42.

Campos, A., \& Vasconcelos, V. (2010). Molecular mechanisms of microcystin toxicity in animal cells. International Journal of Molecular Sciences, 11(1), 268-287. https://doi.org/10.3390/ijms11010268

Cardona, T., Sánchez-Baracaldo, P., Rutherford, A. W., \& Larkum, A. W. (2019). Early Archean origin of Photosystem II. Geobiology, 17(2), 127-150. https://doi.org/10.1111/gbi.12322

Carey. C. C., Haney, J. F., \& Cottingham, K. L. (2007) First report of microcystin-LR in the cyanobacterium Gloeotrichia echinulata. Environ Toxicol 22:337-339. https ://doi.org/10.1002/tox.20245

Carmichael, W. W., Gorham, P. R. (1981) The mosaic nature of toxic blooms of cyanobacteria. In: Carmichael WW (ed) The Water Environment: Algal Toxins and Health. Plenum Press, New York, pp 161-172.

Carmichael, W. W., Jones, C. L. A., Mahmood, N. A., \& Theiss, W. C. (1985) Algal toxins and waterbased diseases. CRC Crit Rev Environ Control15(3):275-303.

Carmichael, W. W., Mahmood, N. A., \& Hyde, E. G. (1990) Natural toxins from cyanobacteria (blue-green) algae. In: Hall S, Strichartz G (eds) Marine Toxins: Origins, Structure and Molecular Pharmacology. American Chemical Society, 87- 106.

Carmichael, W. W. (1994). The toxins of cyanobacteria. Scientific American, 270(1), 78-86. https://doi.org/10.1038/scientificamerican0194-78

Carmichael, W. W., \& Boyer, G. L. (2016). Health impacts from cyanobacteria harmful algae blooms: Implications for the North American Great Lakes. Harmful Algae, 54(April), 194-212. https://doi.org/10.1016/j.hal.2016.02.002

Carmichael, W. W., Sueoka, E., Iida, N., Komori, A., Suganuma, M., Nishiwaki, R., \& Fujiki, H. (1994). Nodularin, a Potent Inhibitor of Protein Phosphatases 1 and 2A, Is a New Environmental Carcinogen in Male F344 Rat Liver. Cancer Research, 54(24), $6402-6406$.

Carpenter, S. R. (2005). Eutrophication of aquatic ecosystems: Bistability and soil phosphorus. Proceedings of the National Academy of Sciences of the United States of America, 102(29), 10002-10005. https://doi.org/10.1073/pnas.0503959102

Catterall, W. A. (2015). Finding channels. Journal of Biological Chemistry, 290(47), 28357-28373. https://doi.org/10.1074/jbc.X115.683383

Chen, L, Chen J, Zhang X, \& Xie P (2015) A review of reproductive toxicity of microcystins. J Hazard Mater 301:381-399

Chen, M., \& Blatchley, E. R. (2020). Chlorine/UV treatment of anatoxin-a by activation of the secondary amine functional group. Environmental Science: Water Research and Technology, 6(5), 1412-1420. https://doi.org/10.1039/c9ew01112a 
Chorus, I., Falconer, I. R., Salas, H. J., \& Bartram, J. (2000). Health risks caused by freshwater cyanobacteria in recreational waters. Journal of Toxicology and Environmental Health - Part B: Critical Reviews, 3(4), 323-347. https://doi.org/10.1080/109374000436364

Chorus, I., Falconer, I. R., Salas, H. J., \& Bartram, J. (2000). Health risks caused by freshwater cyanobacteria in recreational waters. Journal of Toxicology and Environmental Health - Part B: Critical Reviews, 3(4), 323-347. https://doi.org/10.1080/109374000436364

Deeds, J. R. (2008). Non-Traditional Vectors for Paralytic Shellfish Poisoning. Marine Drugs, 6(2), 308-348. https://doi.org/10.3390/md20080015

Devlin, J. P., Edwards, O. E., Gorham, P. R., Hunter, N. R., Pike, R. K., \& Stavric, B. (1977). Anatoxin- a, a toxic alkaloid from Anabaena flos-aquae NRC44h. Canadian Journal of Chemistry, 55(8), 1367-1371. https://doi.org/10.1139/v77-189

Dhanam, S., Sathya, A., \& Elayaraj, B. (2016). Study of physico-chemical parameters and phytoplankton diversity of Ousteri lake in Puducherry. World Scientific News, 54, 153-164.

Dillenberg, H. O., \& Dehne! M. K. (1960) Toxic waterbloom in Saskatchewan, 1959. Can Med Assoc J 83:1151-1154.

Ding, W. X., Shen, H. M., \& Ong, C. N. (2000). Microcystic cyanobacteria extract induces cytoskeletal disruption and intracellular glutathione alteration in hepatocytes. Environmental Health Perspectives, 108(7), 605-609. https://doi.org/10.1289/ehp.00108605

Ding, W. X., Shen, H. M., \& Ong, C. N. (2001). Pivotal role of mitochondrial Ca2+ in microcystin-induced mitochondrial permeability transition in rat hepatocytes. Biochemical and Biophysical Research Communications, 285(5), 1155-1161. https://doi.org/10.1006/bbrc.2001.5309

Ding, W.-X., \& Nam Ong, C. (2003). Role of oxidative stress and mitochondrial changes in cyanobacteria-induced apoptosis and hepatotoxicity. FEMS Microbiology Letters, 220(1), 1-7. https://doi.org/10.1016/S0378-1097(03)00100-9

Dittmann, E., Fewer, D. P., \& Neilan, B. A. (2012). Cyanobacterial toxins: biosynthetic routes and evolutionary roots. FEMS Microbiology Reviews, n/a-n/a. https://doi.org/10.1111/1574-6976.12000

dos Vieira, J. M. S., de P Azevedo, M. T., de Oliveira Azevedo, S. M. F., Honda, R. Y., Corrêa, B. (2003) Microcystin production by Radiocystis fernandoi (Chroococcales, Cyanobacteria) isolated from a drinking water reservoir in the city of Belém, PA, Brazilian Amazonia region. Toxicon 42:709-713

El Saadi, \& Cameron, A. S. (1993) Illness associated with blue-green algae. Med J Aust 158:792-793.

Evans, D. M., Hughes, J., Jones, L. F., Murphy, P. J., Falfushynska, H., Horyn, O., Sokolova, I. M., Christensen, J., Coles, S. J., \& Rzymski, P. (2019). Elucidating cylindrospermopsin toxicity via synthetic analogues: An in vitro approach. Chemosphere, 234 , 139-147. https://doi.org/10.1016/j.chemosphere.2019.06.021

Falconer, I. R., Beresford, A. M., \& Runnegar, M. T. C. (1983). Evidence of liver damage by toxin from a bloom of the blue-green alga, Microcystis aeruginosa. Medical Journal of Australia, 1(11), 511-514. https://doi.org/10.5694/j.1326-5377.1983.tb136192.x

Fawell, J. K., James, .C P., \& James, H. A. (1993) Toxins from blue-green algae: toxicological assessment of microcystin-LR and a method for its determination in water Foundation for Water Research, Marlow, Bucks.

Feng, G., Abdalla, M., Li, Y., \& Bai, Y. (2011). NF-кB mediates the induction of Fas receptor and Fas ligand by microcystin-LR in HepG2 cells. Molecular and Cellular Biochemistry, 352(1-2), 209-219. https://doi.org/10.1007/s11010-011-0756-y

Fiore, M. F., Genuário, D. B., da Silva, C. S. P., Shishido, T. K., Moraes, L. A. B., Cantúsio Neto, R., \& Silva-Stenico, M. E. (2009) Microcystin production by a freshwater spring cyanobacterium of the genus Fischerella. Toxicon 53(7-8):754-761. https ://doi.org/10.1016/j. toxic on.2009.02.010

Fitzgeorge, R. B., Clark, S. A., Keevil, C. W. (1994) Routes of intoxication. In: Codd GA, Jefferies TM, Keevil CW, Potter C (eds) Detection Methods for Cyanobacterial Toxins. Royal Society of Chemistry, London, pp 69-74.

Fu, W. Y., Chen, J. P., Wang, X. M., \& Xu, L. H. (2005). Altered expression of p53, Bcl-2 and Bax induced by microcystin-LR in vivo and in vitro. Toxicon, 46(2), 171-177. https://doi.org/10.1016/j.toxicon.2005.03.021

Greer, B., Maul, R., Campbell, K., \& Elliott, C. T. (2017). Detection of freshwater cyanotoxins and measurement of masked microcystins in tilapia from Southeast Asian aquaculture farms. Analytical and Bioanalytical Chemistry, 409(16), 4057-4069. https://doi.org/10.1007/s00216-017-0352-4

Gupta, N., Pant, S. C., Vijayaraghavan, R., \& Rao, P. V. L. (2003). Comparative toxicity evaluation of cyanobacterial cyclic peptide toxin microcystin variants (LR, RR, YR) in mice. Toxicology, 188(2-3), 285-296. https://doi.org/10.1016/S0300-483X(03)00112-4

Gutiérrez-Praena, D., Jos, A., Pichardo, S., \& Cameán, A. M. (2011). Oxidative stress responses in tilapia (Oreochromis niloticus) exposed to a single dose of pure cylindrospermopsin under laboratory conditions: Influence of exposure route and time of sacrifice. Aquatic Toxicology, 105(1-2), 100-106. https://doi.org/10.1016/j.aquatox.2011.05.015

Gutiérrez-Praena, D., Pichardo, S., Jos, Á., \& María Cameán, A. (2011). Toxicity and glutathione implication in the effects observed by exposure of the liver fish cell line PLHC-1 to pure cylindrospermopsin. Ecotoxicology and Environmental Safety, 74(6), 1567-1572. https://doi.org/10.1016/j.ecoenv.2011.04.030

Halliwell, B., Gutteridge, J. M. C., 1989. Free Radicals in Biology and Medicine, second ed. Claredon Press, Oxford

Harada, K. I., Imanishi, S., Kato, H., Mizuno, M., Ito, E., \& Tsuji, K. (2004). Isolation of Adda from microcystin-LR by microbial degradation. Toxicon, 44(1), 107-109. https://doi.org/10.1016/j.toxicon.2004.04.003.

Hawkins, P. R., Runnergar, M. T. C., Jackson, A. R. B., Falconer, I. R (1985) Severe hepatotoxicity caused by the tropical cyanobacterium (blue-green alga) Cylindromopsis raciborskii (Woloszynska) Seenaya and Subba Raju isolated from a domestic water supply reservoir. Appl Environ Microbiol50(50): 12921295. 
Hermansky, S. J., Stohs, S. J., Eldeen, Z. M., Roche, V. F., \& Mereish, K. A. (1991). Evaluation of potential chemoprotectants against microcystin-LR hepatotoxicity in mice. Journal of Applied Toxicology, 11(1), 65-73. https://doi.org/10.1002/jat.2550110112

Huisman, J., Codd, G. A., Paerl, H. W., Ibelings, B. W., Verspagen, J. M. H., \& Visser, P. M. (2018). Cyanobacterial blooms. Nature Reviews Microbiology, 16(8), 471-483. https://doi.org/10.1038/s41579-018-0040-1

Humpage, A. R., \& Falconer, I. R. (2003). Oral toxicity of the cyanobacterial toxin cylindrospermopsin in male Swiss albino mice: Determination of no observed adverse effect level for deriving a drinking water guideline value. Environmental Toxicology, 18(2), 94-103. https://doi.org/10.1002/tox.10104

\section{Ii, C. (2012). Ecology of Cyanobacteria II. Ecology of Cyanobacteria II. https://doi.org/10.1007/978-94-007-3855-3}

Jang, M. H., Ha, K., Joo, G. J., \& Takamura, N. (2003). Toxin production of cyanobacteria is increased by exposure to zooplankton. In Freshwater Biology (Vol. 48, Issue 9). https://doi.org/10.1046/j.1365-2427.2003.01107.x

Janssen, E. M. L. (2019). Cyanobacterial peptides beyond microcystins - A review on co-occurrence, toxicity, and challenges for risk assessment. Water Research, 151, 488-499. https://doi.org/10.1016/j.watres.2018.12.048

Ji, Y., Lu, G., Chen, G., Huang, B., Zhang, X., Shen, K., \& Wu, S. (2011). Microcystin-LR induces apoptosis via NF- $\mathrm{BB} / \mathrm{iNOS}$ pathway in INS-1 cells. International Journal of Molecular Sciences, 12(7), 4722-4734. https://doi.org/10.3390/ijms12074722

Jochimsen E. M., Carmichael, W. W., An, J., Cardo, D. M., Cookson, S. T., Holmes, C. E. M., Antunes, M. B. de C., Filho de, M. D. A., Lyra, T. M., Barreto, V. S.T., Azevedo, S. M.F.O, \& Jarvis W. R (1998) Liver failure and death after exposure to microcystins at a hemodialysis centre in Brazil. N Eng J Med 338(13):873-878.

Kinnear, S. (2010). Cylindrospermopsin: A decade of progress on bioaccumulation research. Marine Drugs, 8(3), 542-564. https://doi.org/10.3390/md8030542

Kletsas, D., Barbieri, D., Stathakos, D., Botti, B., Bergamini, S., Tomasi, A., Monti, D., Malorni, W., \& Franceschi, C. (1998). The highly reducing sugar 2deoxy-D-ribose induces apoptosis in human fibroblasts by reduced glutathione depletion and cytoskeletal disruption. Biochemical and Biophysical Research Communications, 243(2), 416-425. https://doi.org/10.1006/bbrc.1997.7975

Köker, L., Akçaalan, R., Albay, M., \& Neilan, B. A. (2017). Molecular detection of hepatotoxic cyanobacteria in inland water bodies of the Marmara region, Turkey. Advances in Oceanography and Limnology, 8(1), 52-60. https://doi.org/10.4081/aiol.2017.6394

Kondo, F., Ikai, Y., Oka, H., Okumura, M., Ishikawa, N., Harada, K. ichi, Matsuura, K., Murata, H., \& Suzuki, M. (1992). Formation, Characterization, and Toxicity of the Glutathione and Cysteine Conjugates of Toxic Heptapeptide Microcystins. Chemical Research in Toxicology, 5(5), 591-596. https://doi.org/10.1021/tx00029a002

Kubickova, B., Babica, P., Hilscherová, K., \& Šindlerová, L. (2019). Effects of cyanobacterial toxins on the human gastrointestinal tract and the mucosal innate immune system. Environmental Sciences Europe, 31(1), 1-27. https://doi.org/10.1186/s12302-019-0212-2

Lawton, L. A., \& Codd, G. A. (1991). Cyanobacterial (Blue-Green Algal) Toxins and their Significance in UK and European Waters. Water and Environment Journal, 5(4), 460-465. https://doi.org/10.1111/j.1747-6593.1991.tb00643.x.

Lemasters, J. J., Nieminen, A. L., Qian, T., Trost, L. C., Elmore, S. P., Nishimura, Y., Crowe, R. A., Cascio, W. E., Bradham, C. A., Brenner, D. A., \& Herman, B. (1998). The mitochondrial permeability transition in cell death: A common mechanism in necrosis, apoptosis and autophagy. Biochimica et Biophysica Acta - Bioenergetics, 1366(1-2), 177-196. https://doi.org/10.1016/S0005-2728(98)00112-1

Li, R., Carmichael, W. W., Brittain, S, Eaglesham, G. K., Shaw, G. R., Watanabe, M. M. (2001) First report of the cyanotoxins cylindrospermopsin and deoxycylindrospermopsin from Raphidiopsis curvata (cyanobacteria). J Phycol 37:1121-1126

Li, Y., Sheng, J., Sha, J., \& Han, X. D. (2008). The toxic effects of microcystin-LR on the reproductive system of male rats in vivo and in vitro. Reproductive Toxicology, 26(3-4), 239-245. https://doi.org/10.1016/j.reprotox.2008.09.004

Lippy E. C, \& Erb J (1976) Gastrointestinal illness at Sewickley, Pa. J Am Water Works Assoc 68:606-610.

Llewellyn, L. E. (2006). Saxitoxin, a toxic marine natural product that targets a multitude of receptors. Natural Product Reports, 23(2), 200-222. https://doi.org/10.1039/b501296c

Ma, J., Feng, Y., Jiang, S., \& Li, X. (2017). Altered cellular metabolism of HepG2 cells caused by microcystin-LR. Environmental Pollution, 225, 610-619. https://doi.org/10.1016/j.envpol.2017.03.029

MacKintosh, R. W., Dalby, K. N., Campbell, D. G., Cohen, P. T. W., Cohen, P., \& MacKintosh, C. (1995). The cyanobacterial toxin microcystin binds covalently to cysteine-273 on protein phosphatase 1. FEBS Letters, 371(3), 236-240. https://doi.org/10.1016/0014-5793(95)00888-G

Mahakhant A, Sano T, Ratanachot P, Tong-a-ram T, Srivastava VC, Watanabe MM, Kaya K (1998) Detection of microcystins from cyanobacterial water blooms in Thailand fresh water. Psychol Res 42(s2):25-29. https ://doi.org/10.1046/j.1440-1835.1998.00119 .x

Mahmood W. A, Carmichael W. W (1987) Anatoxin-a(s), an anticholinesterase from the cyanobacteriumAnabaena.flos-aquae NRC-525-17. Toxicon 25(11): 1211-1227.

Malik, J. K., Bharti, V. K., Rahal, A., Kumar, D., \& Gupta, R. C. (2020). Cyanobacterial (blue-green algae) toxins. In Handbook of Toxicology of Chemical Warfare Agents. INC. https://doi.org/10.1016/b978-0-12-819090-6.00031-3 
Matsunaga S, Moore R. E, Niemczura W. P, Carmichael W. W (1989) Anatoxin-a(s), a potent anticholinesterase from Anabaena jlos-aquae. J Am Chern Soc 111:8021-8023.

Melaram, R. (2020). Journal of Earth and Environmental Microcystin Exposure Pathways and Human Health. October.

Meriluoto, J., Spoof, L., \& Codd, G. A. (2016). In Handbook of Cyanobacterial Monitoring and Cyanotoxin Analysis. https://doi.org/10.1002/9781119068761.

Metcalf, J. S., \& Codd, G. A. (2020). Co-occurrence of cyanobacteria and cyanotoxins with other environmental health hazards: Impacts and implications. Toxins, 12(10). https://doi.org/10.3390/toxins12100629

Mohamed, Z., Ahmed, Z., Bakr, A., Hashem, M., \& Alamri, S. (2020). Detection of free and bound microcystins in tilapia fish from Egyptian fishpond farms and its related public health risk assessment. Journal Fur Verbraucherschutz Und Lebensmittelsicherheit, 15(1), 37-47. https://doi.org/10.1007/s00003-01901254-0

Moreira, C., Azevedo, J., Antunes, A., \& Vasconcelos, V. (2013). Cylindrospermopsin: Occurrence, methods of detection and toxicology. Journal of Applied Microbiology, 114(3), 605-620. https://doi.org/10.1111/jam.12048

Nakagawa, H., Munakata, T., \& Sunami, A. (2019). Mexiletine block of voltage-gated sodium channels: Isoform- And state-dependent drug-pore interactions. Molecular Pharmacology, 95(3), 236-244. https://doi.org/10.1124/mol.118.114025

Nong, Q., Komatsu, M., Izumo, K., Indo, H. P., Xu, B., Aoyama, K., Majima, H. J., Horiuchi, M., Morimoto, K., \& Takeuchi, T. (2007). Involvement of reactive oxygen species in Microcystin-LR-induced cytogenotoxicity. Free Radical Research, $41(12), \quad 1326-1337$. https://doi.org/10.1080/10715760701704599

Norris, R. L. G., Seawright, A. A., Shaw, G. R., Senogles, P., Eaglesham, G. K., Smith, M. J., Chiswell, R. K., \& Moore, M. R. (2002). Hepatic xenobiotic metabolism of cylindrospermopsin in vivo in the mouse. Toxicon, 40(4), 471-476. https://doi.org/10.1016/S0041-0101(01)00243-4

Ohtani I, Moore R. E (1992) Cylindrospermopsin: a potent hepatotoxin from the blue-green alga Cylindrospermopsis raciborskii. JAm Chern Soc 114:79417942 .

Pai, M. Systematic reviews and meta-analyses: an illustrated step-by-step guide. The National Medical Journal of India, 17, 86-95.

Pearson, L., Mihali, T., Moffitt, M., Kellmann, R., \& Neilan, B. (2010). On the chemistry, toxicology and genetics of the cyanobacterial toxins, microcystin, nodularin, saxitoxin and cylindrospermopsin. In Marine Drugs (Vol. 8, Issue 5). https://doi.org/10.3390/md8051650

Pflugmacher, S., Wiegand, C., Oberemm, A., Beattie, K. A., Krause, E., Codd, G. A., \& Steinberg, C. E. W. (1998). Identification of an enzymatically formed glutathione conjugate of the cyanobacterial hepatotoxin microcystin-LR: The first step of detoxication. Biochimica et Biophysica Acta - General Subjects, 1425(3), 527-533. https://doi.org/10.1016/S0304-4165(98)00107-X

Pichardo, S., Jos, A., Zurita, J. L., Salguero, M., Cameán, A. M., \& Repetto, G. (2007). Acute and subacute toxic effects produced by microcystin-YR on the fish cell lines RTG-2 and PLHC-1. Toxicology in Vitro, 21(8), 1460-1467. https://doi.org/10.1016/j.tiv.2007.06.012

Prieto, A. I., Jos, Á., Pichardo, S., Moreno, I., \& Cameán, A. M. (2008). Protective role of vitamin E on the microcystin-induced oxidative stress in tilapia fish (Oreochromis niloticus). Environmental Toxicology and Chemistry, 27(5), 1152-1159. https://doi.org/10.1897/07-496.1

Puddick, J., Prinsep, M. R., Wood, S. A., Kaufononga, S. A. F., Cary, S. C., \& Hamilton, D. P. (2014). High levels of structural diversity observed in microcystins from microcystis CAWBG11 and characterization of six new microcystin congeners. Marine Drugs, 12(11), 5372-5395. https://doi.org/10.3390/md12115372

Qiu, T., Xie, P., Liu, Y., Li, G., Xiong, Q., Hao, L., \& Li, H. (2009). The profound effects of microcystin on cardiac antioxidant enzymes, mitochondrial function and cardiac toxicity in rat. Toxicology, 257(1-2), 86-94. https://doi.org/10.1016/j.tox.2008.12.012

Rastogi, R. P., Sinha, R. P., \& Incharoensakdi, A. (2014). The cyanotoxin-microcystins: Current overview. In Reviews in Environmental Science and Biotechnology (Vol. 13, Issue 2, pp. 215-249). Kluwer Academic Publishers. https://doi.org/10.1007/s11157-014-9334-6

Ressom R, Soong F. S, Fitzgerald J, Turczynowicz L, El Saadi, Roder D, Maynard T, \& Falconer I (1994) Health Effects of Toxic Cyanobacterial (Blue-Green Algae National Health and Medical Research Council (NHMRC), Australia, Canberra.

Rinehart, K. L., Harada, K. I., Namikoshi, M., Chen, C., Harvis, C. A., Munro, M. H. G., Blunt, J. W., Mulligan, P. E., Beasley, V. R., Dahlem, A. M., \& Carmichael, W. W. (1988). Nodularin, Microcystin, and the Configuration of Adda. Journal of the American Chemical Society, 110(25), 8557-8558. https://doi.org/10.1021/ja00233a049

Runnegar, M. T. C., Andrews, J., Gerdes, R. G., \& Falconer, I. R. (1987). Injury to hepatocytes induced by a peptide toxin from the cyanobacterium Microcystis aeruginosa. Toxicon, 25(11), 1235-1239. https://doi.org/10.1016/0041-0101(87)90142-5

Runnegar, M. T., Xie, C., Snider, B. B., Wallace, G. A., Weinreb, S. M., \& Kuhlenkamp, J. (2002). In vitro hepatotoxicity of the cyanobacterial alkaloid cyclindrospermopsin and related synthetic analogues. Toxicological Sciences, 67(1), 81-87. https://doi.org/10.1093/toxsci/67.1.81

Schantz, E. J., Ghazarossian, V. E., Schnoes, H. K., Strong, F. M., Spinger, J. P., Pezzanite, J. O., \& Clardy, J. (1975). The Structure of Saxitoxin. Journal of the American Chemical Society, 97(5), 1238-1239. https://doi.org/10.1021/ja00838a045

Schembri M. A, Neilan B. A., \& Saint C. P (2001) Identification of genes implicated in toxin production in the cyanobacterium Cylindrospermopsis raciborskii. Environ Tox 16:413-421

Schreidah, C. M., Ratnayake, K., Senarath, K., \& Karunarathne, A. (2020). Microcystins: Biogenesis, Toxicity, Analysis, and Control. In Chemical Research in Toxicology (Vol. 33, Issue 9). https://doi.org/10.1021/acs.chemrestox.0c00164 
Seifert M, McGregor G, Eaglesham G, Wickramasinghe W, \& Shaw G (2007) First evidence for the production of cylindrospermopsin and deoxycylindrospermopsin by the freshwater benthic cyanobacterium, Lyngbya wollei (Farlow ex Gomont) Speziale and Dyck. Harmful Algae 6:73-80. https ://doi.org/10.1016/j. hal.2006.07.001

Shams S, Capelli C, Cerasino L, \& Ballot A (2015) Anatoxin-a producing Tychonema (cyanobacteria) in European waterbodies. Water Res 69:68-79. https ://doi.org/10.1016/j.watre s.2014.11.006

Sicińska, P., Bukowska, B., Michałowicz, J., \& Duda, W. (2006). Damage of cell membrane and antioxidative system in human erythrocytes incubated with microcystin-LR in vitro. Toxicon, 47(4), 387-397. https://doi.org/10.1016/j.toxicon.2005.12.006

Sivonen K, Carmichael W. W, Namikoshi M, Rinehart K. L, Dahlem A. M, \& Niemela S. I (1991) Isolation and characterization of heptatotoxic microcystin homologs from the filamentous freshwater cyanobacterium Nostoc sp. strain 152. Appl Environ Microbial56:2650-2657.

Sivonen K, Himberg K, Luukkainen R, Niemela S. I, Poon G. K, \& Codd G. A (1989) Preliminary characterization of neurotoxic cyanobacteria blooms and strains from Finland. Toxic Assess 4:339-352.

Sivonen K, \& Jones G (1999) Cyanobacterial toxins. In: Chorus I, Bartram J (eds) Toxic cyanobacteria in water: a guide to public health significance, monitoring and management. E\&FN Spon, London, pp 41-111

Soong F. S, Maynard E, Kirke K, \& Luke C (1992) Illness associated with blue-green algae. Med J Aust 156(1):67.

Sotton, B., Guillard, J., Bony, S., Devaux, A., Domaizon, I., Givaudan, N., Crespeau, F., Huet, H., \& Anneville, O. (2012). Impact of Toxic Cyanobacterial Blooms on Eurasian Perch (Perca fluviatilis): Experimental Study and In Situ Observations in a Peri-Alpine Lake. PLoS ONE, 7(12), 1-12. https://doi.org/10.1371/journal.pone.0052243

Spoof L, Berg K. A, Rapala J, Lahti K, Lepisto L, Metcalf J. S, Codd G. A, \& Meriluoto J (2006) First observation of cylindrospermopsin in Anabaena lapponica isolated from the boreal environment (Finland). Environ Toxicol 21(6):552-560

Spoof L, \& Catherine A (2017) Appendices 3. Tables of microcystins and nodularins. In: Meriluoto J, Spoof L, Codd GA (eds) Handbook of cyanobacterial monitoring and cyanotoxin analysis. Section VIII, Wiley publisher. ISBN: 978-1-119-06868-6

Stevens, D. K., \& Krieger, R. I. (1991). Stability studies on the cyanobacterial nicotinic alkaloid snatoxin-A. Toxicon, 29(2), 167-179. https://doi.org/10.1016/0041-0101(91)90101-V

Stewart I (2004) Recreational exposure to freshwater cyanobacteria: epidemiology, dermal toxicity and biological activity of cyanobacteria lipopolysaccharides. Ph.D. Thesis submitted for the degree of Doctor of Philosophy at the University of Queensland, pp 1-418.

Svirčev, Z., Drobac, D., Tokodi, N., Mijović, B., Codd, G. A., \& Meriluoto, J. (2017). Toxicology of microcystins with reference to cases of human intoxications and epidemiological investigations of exposures to cyanobacteria and cyanotoxins. Archives of Toxicology, 91(2), 621-650. https://doi.org/10.1007/s00204-016-1921-6

Svrcek C, \& Smith D. W (2004) Cyanobacteria toxins and the current state of knowledge on water treatment options: a review. J Environ Eng Sci 3:155-185

Sykora J. L, \& Keleti G (1981) Cyanobacteria and endotoxins in drinking water supplies. In: The Water Environment: Algal Toxins and Health. Plenum Press, New York, pp 285- 302.

Szlag, D. C., Sinclair, J. L., Southwell, B., \& Westrick, J. A. (2015). Cyanobacteria and cyanotoxins occurrence and removal from five high-risk conventional treatment drinking water plants. Toxins, 7(6), 2198-2220. https://doi.org/10.3390/toxins7062198

Takai, A., Eto, M., Hirano, K., Takeya, K., Wakimoto, T., \& Watanabe, M. (2018). Protein phosphatases 1 and $2 \mathrm{~A}$ and their naturally occurring inhibitors: current topics in smooth muscle physiology and chemical biology. Journal of Physiological Sciences, 68(1), 1-17. https://doi.org/10.1007/s12576-017-0556-6

Teixeira, M. R., Rosa, M. J., Sorlini, S., Biasibetti, M., Christophoridis, C., \& Edwards, C. (2020). Removal of Cyanobacteria and Cyanotoxins by Conventional Physical-chemical Treatment. Water Treatment for Purification from Cyanobacteria and Cyanotoxins, 69-97. https://doi.org/10.1002/9781118928677.ch3

Teneva, I., Klaczkowska, D., Batsalova, T., Kostova, Z., \& Dzhambazov, B. (2016). Influence of captopril on the cellular uptake and toxic potential of microcystin-LR in non-hepatic adhesive cell lines. Toxicon, 111, 50-57. https://doi.org/10.1016/j.toxicon.2015.12.006

Turner P. C, Gammie A. J, Hollinrake K, \& Codd G. A (1990) Pneumonia associated with Cyanobacteria. Br Med J 300: 1440-1441

Van Apeldoorn M. E, van Egmond H. P, Speijers G. J. A., \& Bakker G. J. I. (2007) Toxins of cyanobacteria. Mol Nutr Food Res 51:7-60

Wei, Y., Weng, D., Li, F., Zou, X., Young, D. O., Ji, J., \& Shen, P. (2008). Involvement of JNK regulation in oxidative stress-mediated murine liver injury by microcystin-LR. Apoptosis, 13(8), 1031-1042. https://doi.org/10.1007/s10495-008-0237-2

Weng, D., Lu, Y., Wei, Y., Liu, Y., \& Shen, P. (2007). The role of ROS in microcystin-LR-induced hepatocyte apoptosis and liver injury in mice. Toxicology, 232(1-2), 15-23. https://doi.org/10.1016/j.tox.2006.12.010

Wiese, M., D’Agostino, P. M., Mihali, T. K., Moffitt, M. C., \& Neilan, B. A. (2010). Neurotoxic alkaloids: Saxitoxin and its analogs. Marine Drugs, 8(7), 2185-2211. https://doi.org/10.3390/md8072185

Wimmer, K. M., Strangman, W. K., \& Wright, J. L. C. (2014). 7-Deoxy-desulfo-cylindrospermopsin and 7-deoxy-desulfo-12-acetylcylindrospermopsin: Two new cylindrospermopsin analogs isolated from a Thai strain of Cylindrospermopsis raciborskii. Harmful Algae, 37, $203-206$. https://doi.org/10.1016/j.hal.2014.06.006 
Research, Society and Development, v. 10, n. 11, e422101119765, 2021

(CC BY 4.0) | ISSN 2525-3409 | DOI: http://dx.doi.org/10.33448/rsd-v10i11.19765

Wood, R. (2016). Acute animal and human poisonings from cyanotoxin exposure - A review of the literature. Environment International, 91, 276-282. https://doi.org/10.1016/j.envint.2016.02.026

Yan, M., Shen, G., Zhou, Y., Meng, X., \& Han, X. (2020). The role of ERK-RSK signaling in the proliferation of intrahepatic biliary epithelial cells exposed to microcystin-leucine arginine. Biochemical and Biophysical Research Communications, 521(2), 492-498. https://doi.org/10.1016/j.bbrc.2019.10.143

Yoshida T, Makita Y, Nagata S, Tsutsumi T, Yoshida F, Sekijima M, Tamura S. I, \& Ueno Y (1997) Acute oral toxicity ofmicrocystin-LR, a cyanobacterial hepatotoxin, in mice. Nat Toxins 5:91-95.

Yu, S. H (1994) Blue-green algae and liver cancer, In: Steffensen D A, \& Nicholson B. C (eds) Toxic Cyanobacteria, Current Status of Research and Management: International Workshop, 22-26 March 1994, Adelaide, SA. Proceedings, Australian Centre for Water Treatment and Water Quality Research, Salisbury, SA, 22-26.

Zareba, G., Cernichiari, E., Hojo, R., Nitt, S. M., Weiss, B., Mumtaz, M. M., Jones, D. E., Clarkson, T. W., \& Dennis. (2007). Thimerosal distribution and metabolism in neonatal mice: Journal of Applied Toxicology, 27(July), 511-518. https://doi.org/10.1002/jat

Žegura, B., Štraser, A., \& Filipič, M. (2011). Genotoxicity and potential carcinogenicity of cyanobacterial toxins - a review. Mutation Research - Reviews in Mutation Research, 727(1-2), 16-41. https://doi.org/10.1016/j.mrrev.2011.01.002

Zhang, H., Zhang, J., Chen, Y., \& Zhu, Y. (2008). Microcystin-RR induces apoptosis in fish lymphocytes by generating reactive oxygen species and causing mitochondrial damage. Fish Physiology and Biochemistry, 34(4), 307-312. https://doi.org/10.1007/s10695-007-9189-7 